\title{
ZASADA SAMORZĄDU LOKALNEGO W BRYTYJSKICH PROJEKTACH KONSTYTUCJI SKODYFIKOWANEJ
}

\author{
Elżbieta Sadowska-Wieciech \\ Uniwersytet Pedagogiczny im. Komisji Edukacji Narodowej \\ Wydział Pedagogiczny, Katedra Bezpieczeństwa Narodowego \\ e-mail: esadowska@up.krakow.pl
}

\begin{abstract}
Streszczenie: Celem artykułu jest analiza brytyjskich projektów konstytucji skodyfikowanej z perspektywy organizacji, struktury i funkcjonowania władz lokalnych oraz próba odpowiedzi na pytanie o racjonalność dążeń do konstytucjonalizacji zasady samorządu lokalnego w obliczu przeprowadzonych w ostatnich latach reform. Przedmiot rozważań stanowi pozycja ustrojowa brytyjskich samorządów lokalnych oraz możliwości jej ewentualnego umocnienia zarówno przez udzielenie władzom lokalnym wyraźnej konstytucyjnej gwarancji istnienia, jak i za sprawą przekształceń o charakterze ustawowym.
\end{abstract}

Słowa kluczowe: samorząd lokalny, Wielka Brytania, konstytucja skodyfikowana

Jedną z wyraźnych tendencji widocznych w brytyjskiej debacie poświęconej zagadnieniom ustrojowym jest dążenie części środowiska politycznego i akademickiego do zastąpienia konstytucji materialnej jednolitym aktem prawnym charakterystycznym dla państw Europy Kontynentalnej. Chociaż pierwsze postulaty tej rewolucyjnej z anglosaskiego punktu widzenia reformy sięgają lat siedemdziesiątych ubiegłego wieku, kompleksowe plany zmian powstały dopiero dwadzieścia lat później. Wówczas opracowano trzy szeroko analizowane projekty brytyjskiej konstytucji formalnej [Kruk 1993]. Porównywalne znaczenie z analogicznych inicjatyw zyskały jedynie opracowania Vernona Bogdanora, w tym projekt powstały w 2006 roku na Uniwersytecie w Oksfordzie. W dyskusjach dotyczących wspomnianych propozycji najczęściej koncentrowano się na katalogu praw i wolności obywatelskich oraz na przekształceniach systemu wyborczego, należy jednak zaznaczyć, że zawierały one równie istotne rozwiązania w kwestii, której do tej pory odmawiano jednoznacznego umocowania konstytucyjnego. 
Wszystkie dokumenty zawierały bowiem przepisy o władzach lokalnych, czyniąc tym samym zadość postulatom nawołującym do konstytucjonalizacji zasady samorządu lokalnego.

Refleksji nad pozycją ustrojową brytyjskich władz samorządowych towarzyszyła zawsze obawa przed opresyjną polityką rządu centralnego, który wobec braku konstytucyjnych gwarancji istnienia samorządu może arbitralnie decydować nie tylko o jego zadaniach czy uprawnieniach, ale także o istnieniu organów lokalnych. Nastroje te uległy wzmocnieniu w latach osiemdziesiątych XX wieku, kiedy kolejne gabinety Margaret Thatcher prowadziły działania nakierowane na ograniczenie wydatków samorządowych oraz zmianę struktury i organizacji systemu władz lokalnych [Sadowska-Wieciech 2016]. W tym kontekście rozwiązania anglosaskie porównywano z regulacjami charakterystycznymi dla pozostałych państw europejskich, wskazując przede wszystkim na obowiązujące w nich zasady subsydiarności i decentralizacji, a także na regułę domniemania kompetencji na rzecz gminy. Argumentowano, że są one konieczne dla zapewnienia niezależności i swobody działania instytucji samorządowych.

Takie stanowisko prezentują funkcjonujące na terytorium Zjednoczonego Królestwa stowarzyszenia władz lokalnych ${ }^{1}$, a także zdecydowana większość badaczy. Obecnie w związku z przeprowadzonymi reformami samorządów można podać je w wątpliwość, formułując hipotezę o wzmocnieniu pozycji ustrojowej brytyjskich władz lokalnych, która dokonała się w ostatnich latach pomimo niepowodzeń związanych z próbami stworzenia konstytucji skodyfikowanej. W tym kontekście słuszne wydaje się postawienie pytań o stopień realizacji postulatów zawartych w poszczególnych projektach oraz obecny kształt relacji między rządem centralnym a władzami samorządowymi. Uzyskane odpowiedzi umożliwią weryfikację postawionego twierdzenia oraz ocenę zasadności kontynuowania wysiłków zmierzających do konstytucjonalizacji zasady samorządu lokalnego. Jeśli bowiem przyjęto większość proponowanych zmian, racjonalność kontynuowania omawianych dążeń wypada uznać za dyskusyjną.

Mimo znacznego przywiązania do brytyjskiej formuły administrowania sprawami publicznymi oraz przekonania o istnieniu powszechnie akceptowanego konsensu co do wartości i znaczenia władztwa lokalnego, skłaniano się ku rezygnacji z części tradycyjnych elementów anglosaskiej samorządności, takich jak zasada ultra vires czy brak wyraźnego wyodrębnienia organu wykonawczego na rzecz rozwiązań typowych dla modelu kontynentalnego. Argumentowano, że niemieckie czy francuskie regulacje w większym stopniu odpowiadają współczesnym standardom samorządności, chroniąc ją przed nadmierną ingerencją centralnych

${ }^{1}$ Chodzi tu o działające na terytorium Anglii Stowarzyszenie Samorządów Lokalnych (Local Government Association), wraz z formalnie będącym jego częścią Walijskim Stowarzyszeniem Samorządów Lokalnych (Welsh Local Government Association), a także Północnoirlandzkie Stowarzyszenie Samorządów Lokalnych (Northern Ireland Local Government Association) oraz Konwencję Szkockich Władz Lokalnych (Convention of Scottish Local Authorities). 
władz państwowych. Podobną perspektywę wyraziła również działająca w ramach Rady Europy Stała Konferencja Władz Lokalnych i Regionalnych (obecnie Kongres Władz Lokalnych i Regionalnych) w uchwalonej 15 października 1985 r. w Strasburgu Europejskiej Karcie Samorządu Lokalnego.

Dokument ten wskazywał, że zasada samorządu lokalnego powinna być uznana przez prawo krajowe i, o ile to możliwe, także przez konstytucję (art. 2) oraz że wykonywanie zadań na rzecz jednostek powinno przypadać w pierwszej kolejności władzom znajdującym się najbliżej obywateli (art. 4 ust. 3) [Europejska Karta Samorządu Terytorialnego 1994]. Podkreślono także, iż organom samorządowym należy zapewnić wolność podejmowania inicjatyw w każdej kwestii, której nie wyłączono spod ich kompetencji bądź przypisano innej władzy (art. 4 ust. 2), uwidaczniając przy tym powinność rządu centralnego do konsultowania $\mathrm{z}$ organami samorządowymi decyzji związanych z ich funkcjonowaniem (art. 4 ust. 6). Co istotne, analogiczne wskazania zawarto również w zasadach samorządu lokalnego będących elementem Światowej Deklaracji Samorządu Lokalnego opracowanej po raz pierwszy w 1985 r. i zastąpionej podobnym dokumentem uchwalonym w Toronto w 1993 r. przez Międzynarodową Unię Władz Lokalnych [World Wide Declaration of Local Self-Government].

Pomimo iż ówczesne rządy brytyjskie nie zdecydowały się na ratyfikację tych dokumentów, ich treść bez wątpienia wpłynęła na dyskusję dotyczącą pozycji ustrojowej brytyjskiego samorządu lokalnego, znajdując swoje odzwierciedlenie we wspomnianych już projektach konstytucji skodyfikowanej. Pierwszy z nich przedstawili w 1990 r. Liberalni Demokraci, kontynuujący tradycję Partii Liberalnej, która już w programie politycznym z 1979 r. postulowała reformę konstytucyjną, powtarzając ten dezyderat w kolejnych manifestach wyborczych [1979 Liberal Party General Election Manifesto]. Proponowana regulacja, odwołując się do idei decentralizacji oraz zasady subsydiarności, wzmacniała rolę samorządu lokalnego przez przekazanie mu wszystkich zadań, niezastrzeżonych dla innych podmiotów [Macdonald 1990]. Podkreślała również konieczność przeniesienia uprawnień kontrolnych wobec jednostek samorządowych na organy północnoirlandzkie, szkockie i walijskie, tak aby cały proces miał wymiar wyłącznie regionalny.

Szczegółowe propozycje umieszczone w projekcie przewidywały ograniczenie biurokracji przez powołanie jednego tylko podstawowego poziomu samorządu lokalnego (principal authorities) oraz wzmocnienie tzw. pomocniczych jednostek samorządowych (subprincipal authorities), do których zaliczano angielskie parafie oraz szkockie i walijskie wspólnoty. Miano im powierzyć funkcje z zakresu planowania przestrzennego, zarządu terenami zielonymi czy administracji parkingów [Macdonald 1990]. Zmierzano do politycznego i ekonomicznego wzmocnienia struktur lokalnych i regionalnych, rozproszenie władzy postrzegając jako cel główny. W kolejnych miesiącach doprecyzowano te plany, postulując reformę systemu podatków lokalnych, przekazanie organom samorządowym kolejnych kompetencji związanych z opieką zdrowotną, edukacją oraz gospodarką mieszkaniową. Ponadto miano zobligować władze lokalne do opublikowania kart 
określających standardy należnych obywatelom świadczeń oraz zawierających procedury postępowania w razie ich naruszenia [1992 Liberal Democrat General Election Manifesto].

Drugie z omawianych opracowań powstało w 1991 r. w Instytucie Spraw Publicznych (Institute for Public Policy Research), liberalnej organizacji pozarządowej zajmującej się publikacją raportów i ekspertyz dotyczących głównie działalności organów państwowych. Kwestie związane z działaniem samorządu lokalnego umiejscowiono w rozdziale VII, poświęconym władzom krajowym i regionalnym, zaznaczając wyraźnie, że za regulacje dotyczące tego zagadnienia powinny odpowiadać legislatury w Belfaście, Cardiff, Edynburgu i miastach angielskich (jeśli w Anglii zostaną powołane regionalne ciała ustawodawcze). We wstępie wskazano na konieczność decentralizacji władzy państwowej, która jest gwarantem różnorodności i wolności działania na poziomie lokalnym, a także na znaczenie konstytucyjnych gwarancji istnienia samorządu lokalnego, zwłaszcza w kontekście relacji organów samorządowych z administracją centralną.

Podkreślano również wpływ samorządności na rozwój społeczeństwa obywatelskiego oraz różnorodnych form demokracji bezpośredniej. Należy zauważyć, że samorządom zapewniono umocowanie konstytucyjne, nie wprowadzając jednocześnie typowego dla państw unitarnych jednolitego systemu władzy lokalnej, dzięki czemu parlamenty krajowe mogły w nieskrępowany sposób kształtować strukturę i organizację jednostek samorządowych. Pozwalało to na stworzenie odrębnych regulacji prawnych, dzięki czemu organy samorządowe mogły dostosować się do lokalnych uwarunkowań, co z kolei skutkowało lepszym i sprawniejszym zaspokajaniem potrzeb mieszkańców. Odrzucono w ten sposób „demokrację supermarketów, która traktowała obywateli jak konsumentów, pozwalając im wybierać identyczne dobra i usługi w lokalnej gałęzi rządu centralnego", opowiadając się za lokalizmem i różnorodnością.

Najistotniejszą z proponowanych zmian, analogicznie do rozwiązań przedstawionych przez Liberalnych Demokratów było zniesienie w stosunku do władz lokalnych zasady ultra vires na rzecz ogólnej kompetencji do działania (general power of competence), co miało zagwarantować swobodny rozwój wspólnot lokalnych, przyczyniając się jednocześnie do aktywizacji obywateli. W uzasadnieniu powoływano się na ustalenia kolejnych komisji parlamentarnych do spraw samorządu lokalnego (np. Królewskiej Komisji ds. Samorządu Lokalnego lorda Redcliffe-Mauda, i Królewskiej Komisji ds. Samorządu Lokalnego w Szkocji lorda Wheatleya) oraz doświadczenia państw Europy Kontynentalnej, które potwierdzały użyteczność omawianej reguły, szczególnie w zaspakajaniu społecznych i ekonomicznych potrzeb wspólnot lokalnych. Podkreślono także prawo organów samorządu do uchwalania prawa miejscowego, przy czym zaznaczono wyraźnie, że przepisy te nie mogą naruszać ustaw Parlamentu brytyjskiego i legislatur krajowych.

Swoboda działania władz lokalnych jest w znacznej mierze uzależniona od sposobu ich finansowania, dlatego twórcy projektu zapewnili organom samo- 
rządowym prawo do nieskrępowanego nakładania podatku od nieruchomości, stanowiącego niezależne źródło dochodu. W komentarzu do przepisów podkreślono konieczność stworzenia stałych, jasnych regulacji dotyczących finansowania działalności samorządowej, a także ustalenia zakresu oraz formy przyznawanych im dotacji i grantów. Przywołując doświadczenia lat osiemdziesiątych XX wieku, akcentowano potrzebę dostosowania funduszy lokalnych do zadań, jakie powierza się samorządom. Nie bez znaczenia dla nieograniczonego rozwoju demokracji lokalnej, poza aspektem pieniężnym, pozostaje również wyeliminowanie rozwiązań pozwalających na oszustwa bądź manipulacje. Chodzi tu przede wszystkim o kształt prawa wyborczego.

W dokumencie zaznaczono, że granice lokalnych okręgów wyborczych będą ustalane przez legislatury krajowe w porozumieniu z Komisją Wyborczą tak, aby zapobiec ewentualnym manipulacjom (gerrymandering) ${ }^{2}$ oraz zmniejszyć prawdopodobieństwo nadużycia władzy przez grupy polityczne dominujące w poszczególnych jednostkach. Chociaż projekt nie zawiera szczegółowych rozwiązań dotyczących lokalnej ordynacji wyborczej (ta bowiem winna zostać opracowana przez Parlament), wydaje się że Instytut Spraw Publicznych rekomenduje implementację na poziomie samorządowym systemu proporcjonalnego, który sprzyjając mniejszym partiom, rzadziej prowadzi do podporządkowania rady lokalnej jednemu ugrupowaniu politycznemu. Taki podział mandatów w większym stopniu odzwierciedla interesy różnych grup społecznych funkcjonujących w ramach wspólnot lokalnych, wymuszając ciągłą dyskusję oraz dążenie do konsensu [The Constitution 1991].

Projekt konstytucji skodyfikowanej autorstwa laburzystowskiego deputowanego Tony’ego Benna częściowo powtarzał wcześniejsze postulaty [Benn, Hood 1993]. Również w tej propozycji podstawą podziału uprawnień i zadań między samorządami a centrum miały być zasady decentralizacji i subsydiarności, chociaż tej ostatniej nie wyrażono wprost. Za element warunkujący rozwój samorządności uznano ogólną kompetencję do działania, wskazując, że prywatnym firmom i korporacjom funkcjonującym na terytorium Zjednoczonego Królestwa przyznano znacznie szerszy zakres swobody, chociaż bezpośrednio ich celem nie jest zaspokajanie podstawowych potrzeb wspólnot lokalnych. Za konieczne uprawnienia władz lokalnych uznano wykonywanie świadczeń na rzecz obywateli, nawet jeśli byłoby ono finansowane z pożyczek.

Poza tym podkreślono prawo zakupu i utrzymywania nieruchomości, a także udziałów w firmach oraz możliwość tworzenia własnych przedsiębiorstw realizujących zadania o charakterze lokalnym. Radnych upoważniono także do przyznawania grantów i dotacji zarówno organizacjom pożytku publicznego, jak i przedsięwzięciom komercyjnym. Ponadto powierzono im obowiązek bezstron-

2 Terminem tym określa się działanie, które polega na manipulowaniu granicami okręgów wyborczych przez wytyczanie ich w taki sposób, aby zmaksymalizować szanse na zwycięstwo w wyborach aktualnie rządzącej większości. 
nego informowania mieszkańców o podejmowanych inicjatywach przez radio czy telewizję, a także przy pomocy plakatów oraz kolportowanych ulotek. Wskazano przy tym na konieczność prezentowania różnorodnych poglądów, wolnych od uprzedzeń. Co interesujące rady w porozumieniu z mediami mogły wydawać instrukcje dla instytucji publicznych funkcjonujących na terenie podległej im jednostki z poleceniem powstrzymania się od działań, które w ich opinii były szkodliwe dla interesów wspólnoty lokalnej. Przyznano im także prawo wnioskowania o zastąpienie pracownika, którego czyny przyniosły podobny efekt. Taka rekomendacja nabierała mocy wiążącej, chyba że w ciągu sześciu miesięcy od jej wystosowania Izba Gmin na wniosek odpowiedniego ministra stwierdziła, że godzi ona w interesy narodowe.

Jakkolwiek omawiane przepisy przyznawały samorządom wiele nowych uprawnień, w projekcie wyraźnie zaznaczono, że rady lokalne nie mogą podejmować działań, które Parlament w drodze ustawy przyznał innym organom. W przypadku naruszenia tej normy działania te zostaną uznane za niezgodne z prawem, a konsekwencje takiego rozstrzygnięcia poniesie rada jako organ, nie zaś pojedynczy radny. Wyjątek stanowiła sytuacja, w której dopuści się on przestępstwa. Jedyną formą kontroli radnych poza wyborami miały być dochodzenia prowadzone na podstawie oskarżenia o korupcję. Takie rozwiązanie zmierzało do zniesienia indywidualnej odpowiedzialności samorządowców i zmiany ówczesnych przepisów, na mocy których radnych głosujących za uchwałą przesądzającą o podjęciu działań uznanych przez sąd za wykraczające poza uprawnienie ustawowe obciążano kosztami, jakie poniosła określona jednostka w wyniku ich implementacji [Sadowska 2014].

Przekształceniom miał ulec także system nadzoru nad finansami lokalnymi oraz relacje organów samorządowych z miejscowymi jednostkami policji. Sprawozdania z corocznych audytów przeprowadzanych przez kontrolera dystryktu (district auditor) miano przedkładać radzie lokalnej, odpowiedniemu ministrowi oraz Parlamentowi, przy czym kontroler nie miał prawa stwierdzić, że jakieś wydatki są ultra vires, ani obciążyć karą finansową radnych pełniących swoje obowiązki. Odpowiedzialność organów lokalnych zwiększono natomiast w kwestiach dotyczących bezpieczeństwa publicznego, obligując je do uzgadniania wraz z policją priorytetów działania na tej płaszczyźnie. Radom zagwarantowano prawo mianowania i odwołania lokalnego komendanta policji (chief constable), a wszystkie jednostki policji zobowiązano do przedstawiania władzom samorządowym corocznych sprawozdań [Benn, Hood 1993].

Charakter ostatniego z omawianych dokumentów - projektu przygotowanego na seminarium prowadzonym przez V. Bogdanora, jest nieco inny. Jego głównym celem nie było bowiem stworzenie nowych regulacji, ale raczej ujęcie w formie jednego aktu rozwiązań obowiązujących w Zjednoczonym Królestwie na podstawie prawnych i pozaprawnych norm konstytucji nieskodyfikowanej. Za fundament brytyjskich systemów władz lokalnych uznano demokratycznie wybrane władze lokalne, przyznając im prawo nakładania podatków oraz dys- 
krecjonalne kompetencje w zakresie działań służących ekonomicznej, politycznej i społecznej pomyślności obywateli (power of well-being). Uprawnienia te angielskie i walijskie władze lokalne nabyły na mocy Ustawy o samorządzie lokalnym z 2000 r., szkockim samorządom przyznano je trzy lata później, natomiast w Irlandii Północnej zrezygnowano z ich wprowadzenia. Ponadto w opracowaniu wskazano, iż samorządowy organ wykonawczy, którym w tradycji brytyjskiej były powoływane przez radę lokalną komisje, musi przybrać formę gabinetu bądź wybieranego bezpośrednio przez mieszkańców burmistrza [Bogdanor, Khaitan, Vogenauer 2007].

Warto nadmienić, że V. Bogdanor sformułował wiele zasad normujących kwestie związane z funkcjonowaniem samorządu lokalnego, które w jego opinii powinny zostać zawarte w konstytucji formalnej. Należały do nich: reprezentowanie wspólnoty lokalnej przez demokratycznie wybierane władze samorządowe oraz ich prawo do zapewniania usług publicznych leżących w interesie mieszkańców, zniesienie zasady ultra vires, prawo władz lokalnych do posiadania własnych środków finansowych oraz do wyrażania opinii w sprawach zmiany ich struktury, kompetencji czy regulacji dotyczących sposobów finansowania. Badacz podkreślił również, że podział kompetencji i zadań między organami administracji rządowej i samorządowej powinien oprzeć się na zasadzie subsydiarności [Bogdanor 1996]. W jego opinii, jeśli rekomendowane reguły nie zostaną włączone do nowej konstytucji, Wielka Brytania pozostanie państwem scentralizowanym, w którym rząd będzie jedynym podmiotem kształtującym status i funkcje organów lokalnych [Bogdanor 2009].

Wydaje się więc, że oczekiwania twórców projektów brytyjskiej konstytucji skodyfikowanej w odniesieniu do samorządu lokalnego są podobne. Domagają się oni przede wszystkim zagwarantowania władzom samorządowym niezbędnego do ich prawidłowego funkcjonowania stopnia niezależności zarówno na płaszczyźnie organizacyjnej, jak i finansowej. Swoboda działania miałaby zostać wyrażona podziałem zadań na podstawie zasady subsydiarności oraz przyjęciem ogólnej kompetencji do działania. Postulowano ograniczenie dyskrecjonalnych uprawnień rządu oraz upodmiotowienie administracji lokalnej, zwłaszcza w kwestiach bezpośrednio związanych z organizacją i strukturą brytyjskich samorządów. W opracowaniu dotyczącym funkcjonowania władz samorządowych stworzonym przez działającą w Izbie Gmin Komisję ds. reformy politycznej i konstytucyjnej (Political and Constitutional Reform Committee) potwierdzono konieczność tych zmian, zaznaczając, że w kwestiach dotyczących samorządności organy lokalne są partnerem administracji centralnej, nie zaś instytucjami jej podrzędnymi [Illustrative draft Code 2013].

Zwrócono również uwagę na potrzebę nadania radnym prawa decydowania o systemie wyborczym obowiązującym w wyborach lokalnych oraz o układzie organów samorządowych istniejących w każdej jednostce, zaznaczając, że takie zmiany muszą zostać zatwierdzone w referendum lokalnym. Podkreślono pierwotną odpowiedzialność organów lokalnych przed obywatelami oraz konieczność 
instytucjonalizacji współpracy z rządem, tak aby najistotniejsze decyzje zapadały w drodze negocjacji i były poprzedzone szerokimi konsultacjami społecznymi. Ponadto postulowano zagwarantowanie radom lokalnym prawa do podjęcia kroków prawnych, jeśli działania innych podmiotów naruszą niezależność samorządów, wkraczając w ich obszar kompetencji. Naturalnie większość z wymienionych dezyderatów warunkuje kompleksowa reforma sposobu finansowania władz lokalnych, zmierzająca m.in. do przyznania organom samorządowym części wpływów z podatku dochodowego oraz ułatwienia im zaciągania długoterminowych pożyczek, o ile ich ocena kredytowa będzie zadowalająca [Illustrative draft Code 2013].

Chociaż do tej pory w Wielkiej Brytanii nie doszło do uchwalenia konstytucji formalnej, co oznacza brak konstytucyjnych gwarancji istnienia samorządu, część z przytaczanych postulatów zrealizowano. W roku 2011 na mocy Ustawy o lokalizmie [Localism Act 2011], która weszła w życie w lutym 2012 r., angielskim i walijskim władzom lokalnym przyznano ogólną kompetencję do działania, rezygnując tym samym z zasady ultra vires. Należy jednak zaznaczyć, że te ostatnie utraciły nowe uprawnienia na skutek wyników referendum przeprowadzonego 3 marca 2011 r., które przesądzily o przekazaniu Narodowemu Zgromadzeniu dla Walii prawa stanowienia ustaw w kwestiach poddanych dewolucji, w tym w sprawach związanych z samorządem lokalnym. W związku z tym szkockie i walijskie władze lokalne nadal dysponują jedynie dyskrecjonalnymi kompetencjami w zakresie działania na rzecz dobrobytu swoich wspólnot, przy czym rząd walijski w pierwszym kwartale 2017 r. zaprezentował projekt reformy przewidujący nadanie ogólnej kompetencji do działania tamtejszym samorządom [Local Government Reform in Wales 2017]. Z kolei północnoirlandzkie władze lokalne uzyskały ogólną kompetencję do działania w 2014 roku.

Bez wątpienia w wyniku procesu dewolucji spełniono również postulat przeniesienia odpowiedzialności za władze lokalne z Parlamentu brytyjskiego na legislatury krajowe. Obecnie to Narodowe Zgromadzenie dla Walii, Parlament Szkocki oraz Zgromadzenie Północnoirlandzkie tworzą regulacje dotyczące funkcjonowania organów lokalnych w poszczególnych częściach Zjednoczonego Królestwa. Mimo podejmowanych prób nie udało się jedynie utworzyć stabilnych struktur regionalnych w Anglii, które przejęłyby część kompetencji związanych z działaniem władz lokalnych. Wprawdzie w 1998 r. w każdym z ośmiu pozalondyńskich regionów utworzono izby regionalne (regional chambers) odpowiedzialne za koordynowanie polityki lokalnej i opracowywanie strategii rozwojowych, jednak wobec braku poparcia społecznego dla reformy oraz niewydolności nowych struktur już w latach 2008-2010 zostały one zlikwidowane. Równolegle tworzono nowe organy, powierzając im analogiczne zadania - w 2009 roku powołano regionalne rady liderów lokalnych (local authority leaders'boards), jednak również te modyfikacje nie przyniosły oczekiwanych rezultatów.

Jak już wspomniano, szczegółowe dezyderaty dotyczące wzmocnienia pozycji władz lokalnych przewidywały m.in. wprowadzenie na całym terytorium 
Zjednoczonego Królestwa jednego tylko poziomu samorządu. Taką formę przez wzgląd na niewielkie terytorium oraz stosunkowo małą liczbę mieszkańców tradycyjnie posiadał samorząd północnoirlandzki. W Szkocji i Walii zmiany na tym polu przeprowadzono w latach dziewięćdziesiątych ubiegłego wieku, w związku z czym obecnie funkcjonują tam odpowiednio 32 oraz 22 unitarne jednostki samorządowe [Local Government (Scotland) Act 1994, Local Government (Wales) Act 1994]. W Anglii system samorządu lokalnego pozostaje zróżnicowany, ponieważ na części terytorium wciąż działają dwa szczeble władz lokalnych. We wszystkich częściach Wielkiej Brytanii zainicjowano przekształcenia mające na celu wzmocnienie parafii i wspólnot oraz zwiększenie odpowiedzialności radnych za porządek publiczny i bezpieczeństwo. Do najbardziej interesujących zmian na ostatniej z wymienionych płaszczyzn należy powołanie w $2011 \mathrm{r}$. w Anglii i Walii lokalnych komisarzy ds. policji i przestępczości (police and crime commissioner).

Pomimo iż wszystkie najważniejsze siły polityczne deklarują poparcie dla decentralizacji oraz zwiększenie niezależności finansowej organów samorządowych, a w swoich programach politycznych zobowiązują się do przekazania władzom lokalnym dodatkowych funkcji, w praktyce kolejne gabinety w bardzo ograniczonym stopniu realizują przedwyborcze zobowiązania [Change Britain's Future 2017, Forward Together 2017, For the Many not the Few 2017]. Formalnie wciąż nie zagwarantowano, że podział zadań i kompetencji między centrum a samorządami będzie dokonywał się na podstawie zasady subsydiarności. Ponadto wysokość funduszy pozostających w dyspozycji radnych nadal w znacznym stopniu zależy od decyzji ministerialnych, natomiast wszelkie przekształcenia mające na celu rewitalizację i wzmocnienie władztwa lokalnego nie naruszyły scentralizowanej struktury administracji brytyjskiej, co oznacza, że rząd może traktować samorządy w sposób instrumentalny, podporządkowując je wymogom bieżącej sytuacji politycznej [Blick 2015].

Realizacja niektórych postulatów zwolenników konstytucjonalizacji zasady samorządu lokalnego przyczyniła się do częściowego wzmocnienia pozycji ustrojowej władz lokalnych, co podaje w wątpliwość nie tylko sens kontynuowania tych dążeń, ale także podnosi pytania o ich skuteczność. Nie wydaje się bowiem, aby ustawowy charakter wprowadzonych innowacji wpłynął na ich implementację. Można przypuszczać, że normy konstytucyjne, zwłaszcza w projektach, które nie przewidywały ich wyższej mocy prawnej, funkcjonowałyby podobnie. Co więcej proponowane przepisy przez wzgląd na swoją naturę ujmowały kwestie samorządowe dosyć ogólnie, pozostawiając tym samym wiele zagadnień do uregulowania ustawowego. Oznacza to, że czynnik, który w największym stopniu determinuje działania organów lokalnych, czyli wysokość dostępnych zasobów finansowych, nadal pozostawałby w gestii rządu.

Należy również zauważyć, że asymetryczna relacja między władzami lokalnymi a centrum wynika nie tylko z braku konstytucyjnych gwarancji istnienia tych ostatnich, ale przede wszystkim z konstrukcji całego systemu politycznego. Jakkolwiek bowiem formalnie ustrój organów samorządowych może być do- 
wolnie kształtowany w drodze ustawy, w praktyce działania zmierzające do ich całkowitego zniesienia są niemożliwe. Ponadto nawet w warunkach brytyjskich przez odwołanie się do zasady ograniczonego rządu mogłyby one zostać uznane za niekonstytucyjne [Jones, Travers 1996]. Chociaż reformy samorządowe ostatnich lat, zwłaszcza w porównaniu z działaniami gabinetów w latach 1979-1997, w pewnym stopniu wzmocniły pozycję samorządu, to należy się zgodzić z badaczami podkreślającymi ich stosunkowo nietrwały charakter. Może się bowiem zdarzyć, że przyszłe rządy przyjmą takie polityczne priorytety, które będą skutkować ograniczeniem praw władz lokalnych na rzecz innych podmiotów. Jeśli tak się zdarzy, kwestią otwartą pozostaje to, czy konstytucyjne gwarancje istnienia samorządu, przyjęte w którymś z proponowanych kształtów faktycznie uchroniłyby samorząd przed ewentualnymi zmianami.

Title: The Principle of Local Self-Government in British Codified Constitution Projects

\begin{abstract}
Local government in the United Kingdom is subject to constant change because there is no constitutional protection of it. It means that central government can freely determine its structure, organization and functions without even the need to consult local authorities. That is the reason why there has been growing support for the constitutionalisation of local government. This article presents conceptions of British local government presented in the most important projects of the codified constitution for the United Kingdom. It discusses the arguments presented both for and against the constitutionalisation of local government and explores the meaning of the process for local government in the British political system.
\end{abstract}

Keywords: local government, Great Britain, codified constitution

\title{
BIBLIOGRAFIA
}

1. 1979 Liberal Party General Election Manifesto, The Real Fight is for Britain, http://www. libdemmanifesto .com/1979/1979-liberal-manifesto.shtml.

2. 1992 Liberal Democrat General Election Manifesto, Changing Britain for good, http://www. libdemmanifesto. com /1992/19 92-liberal-manifesto.shtml.

3. Benn T., Hood A., 1993, Common Sense: A New Constitution for Britain, Hutchinson, London, s. 99,141 .

4. Blick A., 2015, Beyond Magna Carta, A Constitution for the United Kingdom, Oxford University Press, Oxford, s. 177.

5. Bogdanor V., 2009, The New British Constitution, Hart, Portland, s. 269.

6. Bogdanor V., 1996, Politics and the Constitution. Essays on British Government, Dartmouth Pub. Co., Aldershot 1996, s. 165-171.

7. Bogdanor V., Khaitan T., Vogenauer S., 2007, Should Britain Have a Written Constitution?, "Political Quarterly", nr 78 (4), s. 511.

8. Change Britain's Future, 2017, Liberal Democrats, London, s. 64.

9. Europejska Karta Samorządu Terytorialnego, Dz.U. 1994, nr 124, poz. 607. 
10. For the Many Not the Few, 2017, Labour Party, London, s. 86.

11. Forward Together, Our Plan for a Stronger Britain and a Prosperous Future, 2017, Conservative Party, London, s. 32.

12. Illustrative draft Code for central and local government, 2013, Political and Constitutional Reform Committee, London, s. 1-4.

13. Jones G., Travers T., 1996, Central Government Perceptions of Local Government, [in:] Local Democracy and Local Government, Macmillan Press, Basingstoke, s. 92.

14. Kruk M., 1993, Nowe projekty brytyjskiej konstytucji pisanej, „Państwo i Prawo” z. 8, s. 70-78.

15. Local Government Reform in Wales, Lawyers in Local Government, http://www.lawyersinlocalgovernment.org.uk/news_articles/local-government-reform-in-wales.

16. Local Government (Scotland) Act 1994, 1994, c. 39.

17. Local Government (Wales) Act 1994, 1994, c. 19.

18. Localism Act 2011, 2011, c. 20.

19. Macdonald J., 1990, A Draft Constitution for the United Kingdom, [in:] „, We the People...” Towards a Written Constitution, Appendix 2, London, s. 22-23.

20. Sadowska-Wieciech E., 2016, Polityka rzadów Margaret Thatcher wobec samorzadu lokalnego w latach 1979-1990, [w:] Konstytucjonalizm, doktryny, partie polityczne. Księga dedykowana profesorowi Andrzejowi Ziębie, Wyd. UJ, Kraków, s. 617-628.

21. Sadowska E., 2014, Brytyjski samorzad lokalny po 1945 roku, Wyd. UJ, Kraków, s. 99.

22. The Constitution of the United Kingdom, 1991, Institute for Public Policy Research, London, s. 20-21, 73-74.

23. World Wide Declaration of Local Self-Government, International Union of Local Authorities, http://www.bunken.nga.gr.jp/siryousitu/eturansitu/charter/iula_decl_txt.html. 